\section{NIH asked to budget for flat funding for management costs}

\begin{abstract}
Washington. Harold Varmus, director of the US National Institutes of Health (NIH), has been told by a leading congressman to assume that the agency's budget for research management and support will be held flat for the three fiscal years that begin in 1998 . This support budget was cut by 7.5 per cent, to $\$ 481$ million, in 1996 , a figure that was maintained in 1997, the current fiscal year that began on 1 October.
\end{abstract}

John Porter (Republican, Illinois), chairman of the subcommittee of the House appropriations committee that oversees NIH's $\$ 12.7$ billion budget, made known his plans for the support budget late last month in a letter to Varmus. He asked Varmus to conduct a comprehensive review of the NIH's administrative structure and costs by next June, and to produce a long-range research management plan assuming "level funding" - with no inflation adjustment for the next three years.

Officials have argued that flat administrative budgets make it difficult to support the growing extramural activity stimulated by the agency's overall budget boosts in 1996 and 1997. But an aide to Porter points out that administrative budgets were held flat in 1997 across all the departments in the subcommittee's jurisdiction, including labor, health and human services and education. the same."

M. W.

\section{Gibbons 'has no plans to leave government'}

Washington. Jack Gibbons, director of the White House Office of Science and Technology Policy (OSTP) and science adviser to President Bill Clinton, said last week he "has no plans to leave the government at this time", and has laid out an agenda for OSTP in the first half of 1997. But he did not commit himself to serving a full second term with the Clinton administration, saying he had yet to discuss it with the president.

Gibbons said that the office will continue to work on international scientific collaboration, engage in "constructive dialogue" with Congress on funding for the National Aeronautics and Space Administration (NASA) and the future structure of the Department of Energy, and seek to develop an "innovative partnership" with state governments.

The office plans additional major meetings in the first half of next year with state governments and universities, officials say. Gibbons said that he intends to "spend more time outside the office" and to meet more scientists outside Washington in future.

Colin Macilwain

\title{
Commercial backing 'could impair academic influence'
}

Washington. A study of US researchers in the life sciences has warned against too high a level of industrial sponsorship for research at universities. Beyond a certain level of industrial sponsorship, academic productivity and influence appear to fall off without a commensurate increase in commercial productivity, says the study.

The study was sponsored by the US National Center for Human Genome Research, and the results were published last week in The New England Journal of Medicine (335, 1734-1739; 1996). Its broad message is that industry-sponsored scientists are at least as academically productive as those who do not rely on industry funding and much more commercially productive.

But it confirms that sponsored scientists are more prone to secrecy, to choosing research topics with an eye to commercial ends, and to refusing to share materials or research results with colleagues. The authors of the study also conclude that: "Beyond some point, increases in the participation of academic institutions in relation-

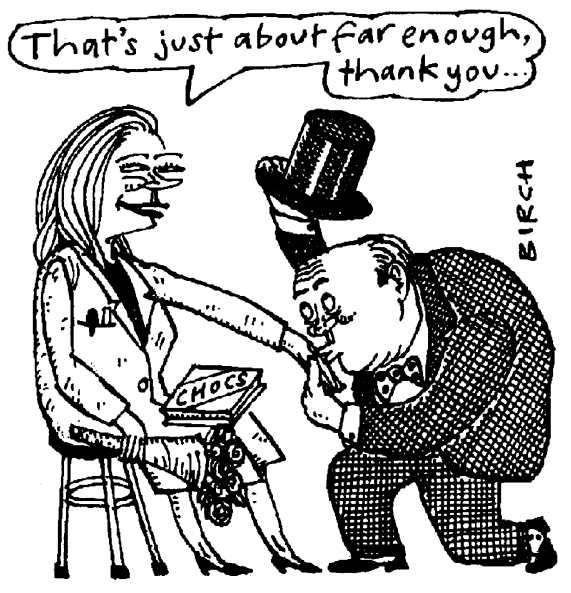

ships with industry may have costs that outweigh their benefits."

The study was based on information supplied by 2,052 faculty members at 50 leading US universities in 1994 and 1995. Among respondents, 28 per cent reported receiving industry support.

A limited amount of corporate funding appears linked to above-average scientific performance. Faculty members who reported receiving up to one-third of their total research budgets from industry outperformed non-industry funded colleagues in both rates and influence of their publications, as well as in their administrative involvement at their institutions.

But these effects fell off with increasing industry support, most markedly among those receiving more than two-thirds of their budgets from industry. And, in the category of publication influence, this group was surpassed by faculty members who were not supported by industry. The highest rate of commercial outcomes, ranging from patent applications to new products and companies, came from scientists receiving between one- and two-thirds of their funding from industry.

The authors, led by David Blumenthal, chief of health policy research at Massachusetts General Hospital in Boston, write that comparison with a 1985 study shows that these broad conclusions have remained "remarkably stable" over the decade. The conclusions, they write, suggest that relationships between academic institutions and industry "enhance commercial productivity among distinguished academic investigators and do not compromise their participation in traditional academic activities".

But there was a significant difference in the proportion of scientists likely to pick research topics with an eye on commercial applicability. Thirty-five per cent of industry-supported scientists said that they did this, compared with 14 per cent of academics who were not funded by industry.

Similarly, 14.5 per cent of industry-sponsored scientists said that trade secrets defined as information kept secret to protect its proprietary value - had resulted from their work. Only 4.7 per cent of non-industry funded scientists said the same. Among industry-sponsored faculty, 11.1 per cent said that they had refused requests from colleagues to share biological materials or research results; 5.8 per cent of non-industry funded scientists said the same.

"The bottom line for me is that these relationships are working but have risks," says Blumenthal. The authors write that universities should be "vigilant" because of the greater tendency among industry-sponsored scientists to keep their results secret, and the skewing of research topics towards commercial ends.

Steven Rosenberg, chief of surgery at the National Cancer Institute, calls it "ghastly" that 14.5 per cent of industry-sponsored scientists admitted to keeping trade secrets. "We are not trying to build a better refrigerator. We are trying to save lives," says Rosenberg. "Keeping secrets is contrary to that ethic."

But industry organizations welcomed the conclusion of the study that industrysupported scientists are excelling academically and commercially. Society is "getting a good bang for its buck with the industry process," says David A Shriver, assistant vice-president for academic affairs at the Pharmaceutical Research and Manufacturers of America.

Meredith Wadman 